\title{
Nitrogen Uptake and Allocation at Different Growth Stages of Young Southern Highbush Blueberry Plants
}

\author{
Yang Fang, Jeffrey Williamson, and Rebecca Darnell \\ Horticultural Sciences Department, University of Florida, Gainesville, FL \\ 32607
}

Yuncong Li
Department of Soil and Water Sciences, Tropical Research and Education
Center, IFAS, University of Florida, Homestead, FL 33031

Guodong Liu ${ }^{1}$

Horticultural Sciences Department, University of Florida, Gainesville, FL 32607

Additional index words. dry weight, isotope, ${ }^{15} \mathrm{~N}$, Vaccinium corymbosum

\begin{abstract}
Southern highbush blueberry (SHB, Vaccinium corymbosum L. interspecific hybrid) is the major species planted in Florida because of the low-chilling requirement and early ripening. The growth pattern and nitrogen $(\mathrm{N})$ demand of SHB may differ from those of northern highbush blueberry (NHB, $V$. corymbosum $\mathrm{L}$.). Thus, the effect of plant growth stage on $\mathrm{N}$ uptake and allocation was studied with containerized 1-year-old SHB grown in pine-bark amended soil. Five 'Emerald' plants were each treated with $6 \mathrm{~g} \mathrm{10 \%}$ ${ }^{15} \mathrm{~N}$ labeled $\left(\mathrm{NH}_{4}\right)_{2} \mathrm{SO}_{4}$ at each of 12 dates over 2 years. In the first year, plants were treated once in late winter, four times during the growing season, and once in the fall. In the second year, treatment dates were based on phenological stages. After a 14-day chase period following each ${ }^{15} \mathrm{~N}$ treatment, plants were destructively harvested for dry weight (DW) measurements, atom $\%$ of ${ }^{15} \mathrm{~N}$, and $\mathrm{N}$ content of each of the plant tissues. Total DW increased continuously from mid-May 2015 to Oct. 2015 and from Mar. 2016 to late Sept. 2016. From August to October of both years, external $N$ demand was the greatest and plants absorbed more $\mathrm{N}$ during the 2-week chase period, about $0.53 \mathrm{~g} / \mathrm{plant}$ in year 1 and $0.67 \mathrm{~g} /$ plant in year 2, than in chase periods earlier in the season. During March and April, $\mathrm{N}$ uptake was as low as $0.03 \mathrm{~g} / \mathrm{plant} / 2$ weeks in year 1 and $0.21 \mathrm{~g} / \mathrm{plant} / 2$ weeks in year 2. Nitrogen allocation to each of the tissues varied throughout the season. About half of the $\mathbf{N}$ derived from the applied fertilizer was allocated to leaves at all labeling times except the early bloom stage in 2016. These results suggest that young SHB plants absorb greater amounts of $\mathrm{N}$ during summer and early fall than in spring.
\end{abstract}

Blueberry (Vaccinium spp.) plants in Florida are typically grown on sandy soils where the risk of $\mathrm{N}$ loss via leaching is greater than on clay soils (Whitehead and Raistrick, 1993). Although cultivated blueberry grows optimally with ammonium as the $\mathrm{N}$ source, and ammonium is typically not as readily leachable as nitrate, significant leaching of both $\mathrm{N}$ forms occurs on coarse-textured sandy soils (Vitosh et al., 1995). In addition, the rainy season in Florida is from late spring through early fall, which coincides with the

Received for publication 9 Jan. 2017. Accepted for publication 8 May 2017.

This study was financially supported by USDA-AMS through 2014 Florida Specialty Crop Block Grant program (Contract no. 00096225). We thank professors Ed Hanlon and Don Huber at the University of Florida for reviewing the article. We would appreciate Island Grove Ag Products: Nursery Division for providing free blueberry plants and pine bark, Eric Ostmark for his help in managing the trial and James Colee for his assistance on statistical analysis.

${ }^{1}$ Corresponding author. E-mail: guodong@ufl.edu. time when commercial blueberry growers apply $\mathrm{N}$ fertilizer. It is commonly understood that heavy rainfall increases $\mathrm{N}$ leaching (Gheysari et al., 2009; Wild and Cameron, 1980). In addition, blueberry plants are shallow-rooted, with roots concentrated mostly in the top $0.15 \mathrm{~m}$ (Williamson and Miller, 2009). Thus, there is a high risk for $\mathrm{N}$ leaching and an increased potential for ground or surface water contamination where blueberry is grown on sandy soils in humid, subtropical climates.

Split applications of $\mathrm{N}$ may extend the time of $\mathrm{N}$ bioavailability for plant uptake and have been reported to promote yield or plant growth compared with a single application. For example, mature blueberry plants had a $10 \%$ yield increase (Hanson and Retamales, 1992), red raspberry (Rubus idaeus L.) ended up with a significantly greater berry yield (Rempel et al., 2004), and lowbush blueberry ( $V$. angustifolium) plants increased both growth and berry yield significantly (Percival et al., 2002).

Storage and remobilization of $\mathrm{N}$ in perennial woody species such as blueberry help plants reduce dependency on fertilizer $\mathrm{N}$ (Geßler et al., 1998; Millard, 1996). Remobilization of storage $\mathrm{N}$ accounted for $\approx 65 \%$ of the total $\mathrm{N}$ in new vegetative growth of 'Climax' rabbiteye blueberry ( $V$. virgatum Ait.) at vegetative budbreak (Birkhold and Darnell, 1993). Cheng and Fuchigami (2002) found that $50 \%$ of reserve $\mathrm{N}$ in apple (Malus domestica Borkh.) trees was remobilized to support new growth of shoots and leaves. Some species of woody plants can remobilize up to $90 \%$ of reserve $\mathrm{N}$ to new leaf growth (Millard, 1996). Thus, with sufficient $\mathrm{N}$ storage, plants can be less dependent on $\mathrm{N}$ fertilizer. However, $\mathrm{N}$ remobilization is closely related to plant phenology (Millard and Grelet, 2010).

Banados (2006) concluded that $\mathrm{N}$ uptake in mature NHB $(V$. corymbosum $\mathrm{L}$.) is more dependent on plant demand than on $\mathrm{N}$ availability in the soil. Thus, an effective $\mathrm{N}$ fertilization program requires a clear understanding of the times when $\mathrm{N}$ fertilizer is most needed. Previous studies have found that the effect of application date on $\mathrm{N}$ absorption by blueberry plants is significant (Banados, 2006; Hanson and Retamales, 1992; Throop and Hanson, 1997). However, these studies used the midseason NHB cultivar 'Bluecrop'. Southern highbush blueberry (V. corymbosum L. interspecific hybrid) cultivars that are adapted to Florida's mild winter climate ripen fruit earlier in the season and have a longer postfruit harvest vegetative growth period than NHB cultivars. Therefore, seasonal growth and $\mathrm{N}$ demand of SHB may differ from NHB. However, there is no literature available for the seasonal growth and $\mathrm{N}$ demand pattern of young SHB plants. This study was conducted to 1) determine seasonal growth of SHB by measuring organ DW at various growth stages, 2) identify the growth stages of young SHB that exhibit the greatest $\mathrm{N}$ uptake, and 3) determine $\mathrm{N}$ allocation patterns within plant tissues.

\section{Materials and Methods}

Plant material. Sixty one-year-old 'Emerald' (SHB) plants (average height $0.19 \mathrm{~m}$ ) were obtained from a north Florida nursery and individually planted in 57-L containers on 6 Feb. 2015 and grown outdoors at the Horticultural Greenhouse Complex at the University of Florida, Gainesville, FL $\left(29^{\circ} 38^{\prime} \mathrm{N}\right.$ latitude and $82^{\circ} 21^{\prime} \mathrm{W}$ longitude). The growing medium consisted of Arredondo sandy soil (Thomas et al., 1979) mixed with fresh pine bark at the ratio of $1: 1(\mathrm{v} / \mathrm{v})$. Owing to the potential for fresh pine bark to immobilize fertilizer $\mathrm{N}$, it was pretreated 2 months before planting with a liquid fertilizer UAN$32(32 \mathrm{~N}-0 \mathrm{P}-0 \mathrm{~K})$ at the rate of $0.15 \mathrm{~g} / \mathrm{L} \mathrm{N}$ (Krewer and Ruter, 2009).

Treatments. Treatments consisted of applying $10 \%{ }^{15} \mathrm{~N}$ labeled fertilizer as ammonium sulfate $\left[\left(\mathrm{NH}_{4}\right)_{2} \mathrm{SO}_{4}\right]$ at six different growth stages during each of the two growing seasons. In the first growing season (2015), flowers were removed to encourage vegetative growth. Vegetative growth occurred 


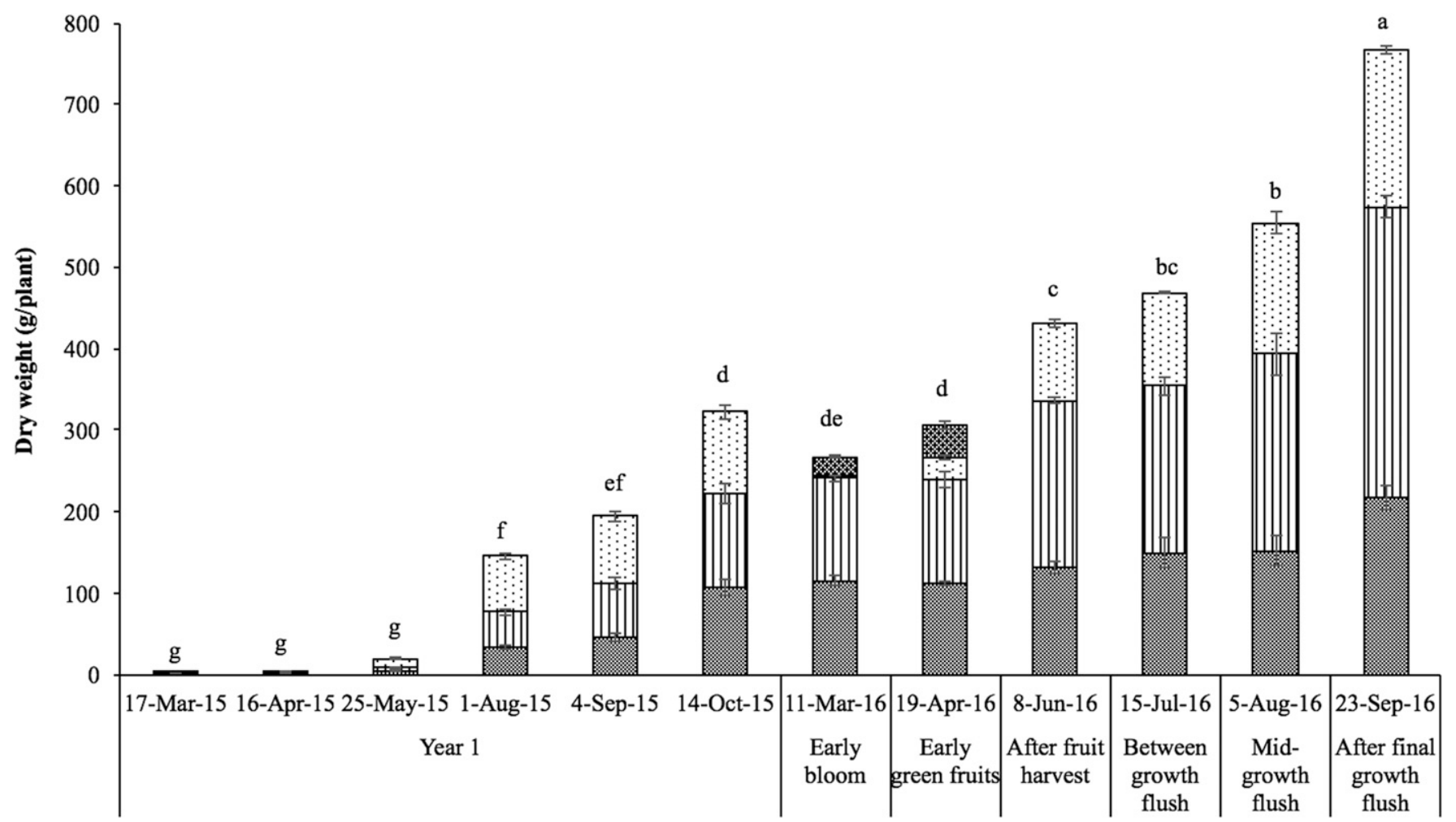

- root $\square$ stem $\square$ leaf 圈 flower/fruit

Fig. 1. Dry weight (DW) of young 'Emerald' blueberry plants grown in 57-L containers throughout two growing seasons in 2015 and 2016 . Means \pm SE $(n=5)$. The DW of stem is the sum of the DW of one-year-old stems and new stems. Means with different letters indicate significant differences in total DW at $P \leq 0.05$ according to Tukey's honestly significant difference test.

continuously from early March to late September, and individual growth flushes were not evident. Thus, treatment dates were not based on plant phenology. The ${ }^{15} \mathrm{~N}$ treatment dates were 3 Mar. ( $25 \mathrm{~d}$ after budbreak), 2 Apr., 11 May, 18 July, 21 Aug., and 30 Sept. (after vegetative growth stopped). In the second growing season (2016), the ${ }^{15} \mathrm{~N}$ treatments were applied on 26 Feb. (early bloom), 5 Apr. (early green fruit stage), 25 May (10 d after the final fruit harvest), 1 July (between growth flushes), 22 July (midgrowth flush), and 9 Sept. (after the final vegetative flush). Each growth flush ceased when the uppermost bud aborted, and the next flush began when buds burst near the tip. On each of the six dates either year, five plants were treated with $6 \mathrm{~g}{ }^{15} \mathrm{~N}$ labeled $\left(\mathrm{NH}_{4}\right)_{2} \mathrm{SO}_{4}(1.26 \mathrm{~g} \mathrm{~N})$, and the other plants were treated with the same amount of $\mathrm{N}$ from unlabeled $\left(\mathrm{NH}_{4}\right)_{2}$ $\mathrm{SO}_{4}$. The five ${ }^{15} \mathrm{~N}$ treated plants were destructively harvested for analysis after $14 \mathrm{~d}$. The treatments were arranged in a randomized complete block design with five singleplant replications.

In the first year, there was a long period between the third fertilization date (11 May) and the fourth date (18 July); therefore, unlabeled $\mathrm{N}$ was applied on 16 June. Thus, the rate of $\mathrm{N}$ fertilization was equivalent to 38 $\mathrm{kg} / \mathrm{ha} \mathrm{N}(0.85 \mathrm{~m} \times 2.74 \mathrm{~m}$ spacing $)$ in year 1 and $33 \mathrm{~kg} / \mathrm{ha} \mathrm{N}$ in year 2 . Both labeled and unlabeled $\mathrm{N}$ fertilizers were dissolved in water and applied manually and evenly on soil around the root systems. At the same time as the $\mathrm{N}$ applications, $3.6 \mathrm{~g}$ triple superphosphate $(0 \mathrm{~N}-19.6 \mathrm{P}-0 \mathrm{~K})$ and $6.8 \mathrm{~g}$ sulfate of potash $(0 \mathrm{~N}-0 \mathrm{P}-41.5 \mathrm{~K})$ were applied to each pot $(49 \mathrm{~kg} \mathrm{P} / \mathrm{ha}$ and $103 \mathrm{~kg} \mathrm{~K} / \mathrm{ha}$ in year 1 and $42 \mathrm{~kg} \mathrm{P} / \mathrm{ha}$ and $88 \mathrm{~kg} \mathrm{~K} / \mathrm{ha}$ in year 2 ). The plants were irrigated by microsprinklers at $250 \mathrm{~mL} / \mathrm{min}$, and the irrigation run times were determined by multiplying the in situ evapotranspiration (ET) by 1.2 (based on $120 \%$ ET level). The ET data were downloaded twice a month from the Florida Automated Weather Network (FAWN) Alachua station (http://fawn.ifas. ufl.edu).

Measurements. Harvested plants were separated into leaves, new (current season's) stems, 1-year-old stems, roots, and flowers/ fruits when available. The roots were carefully excavated from the containers. Then, they were pressure washed (up to 80 pounds per square inch, PSI) using a Melnor 5Pattern Watering Nozzle (Model no.: 20101GT; BFG Supply, Burton, OH) to remove the soil and pine bark. Tissues were individually oven-dried at $65^{\circ} \mathrm{C}$ to a constant weight which was recorded. Total DW was the sum of the DW of each of the tissues. The tissues were ground with a laboratory mill (Arthur H. Thomas Company, Philadelphia, PA) into a powder passing a 2-mm mesh screen. Subsamples of leaf $(1 \mathrm{mg})$, flower and fruit $(3 \mathrm{mg})$, stem $(4 \mathrm{mg})$, and root $(4 \mathrm{mg})$ tissues were submitted to the Soil and Water
Science Biogeochemistry Core Laboratory (University of Florida, Gainesville, FL) to determine atom $\%$ of ${ }^{15} \mathrm{~N}$ and $\mathrm{N}$ concentration by using an isotope ratio mass spectrometer (Finnigan DELTAplus XP; Thermo Fisher Scientific, Bremen, Germany). Nitrogen derived from fertilizer (NDFF) represented the total amount of $\mathrm{N}$ from labeled fertilizer absorbed by plants during a 14-d chase period after ${ }^{15} \mathrm{~N}$ treatment. Fraction of total $\mathrm{N}$ derived from fertilizer (\%NDFF) and NDFF were calculated according to Danso et al. (1983) as follows:

$$
\begin{gathered}
\% N D F F=\frac{{ }^{15} N_{n a}-{ }^{15} N_{s}}{{ }^{15} N_{n a}-{ }^{15} N_{f}} \times 100 \\
N D F F(g)=\% N D F F \times N_{c} \times D W(g)
\end{gathered}
$$

where ${ }^{15} N_{n a}$ is ${ }^{15} \mathrm{~N}$ natural abundance, $0.336 \%$ (Mariotti, 1983), ${ }^{15} N_{s}$ represents ${ }^{15} \mathrm{~N}$ atom percent of sample and ${ }^{15} N_{f}$ denotes that of fertilizer, $10 \%$. $N_{c}$ means $\mathrm{N}$ content, $\mathrm{g} \mathrm{N}$ per g DW of subsamples.

Plant height was measured six to seven times a year. In the second year, the area covered by the plant canopy was calculated by measuring the canopy width in two orthogonal directions and calculating the area of the ellipse. Plants were not pruned during the study as plants are not typically pruned until the third year after planting in commercial blueberry production in Florida. 


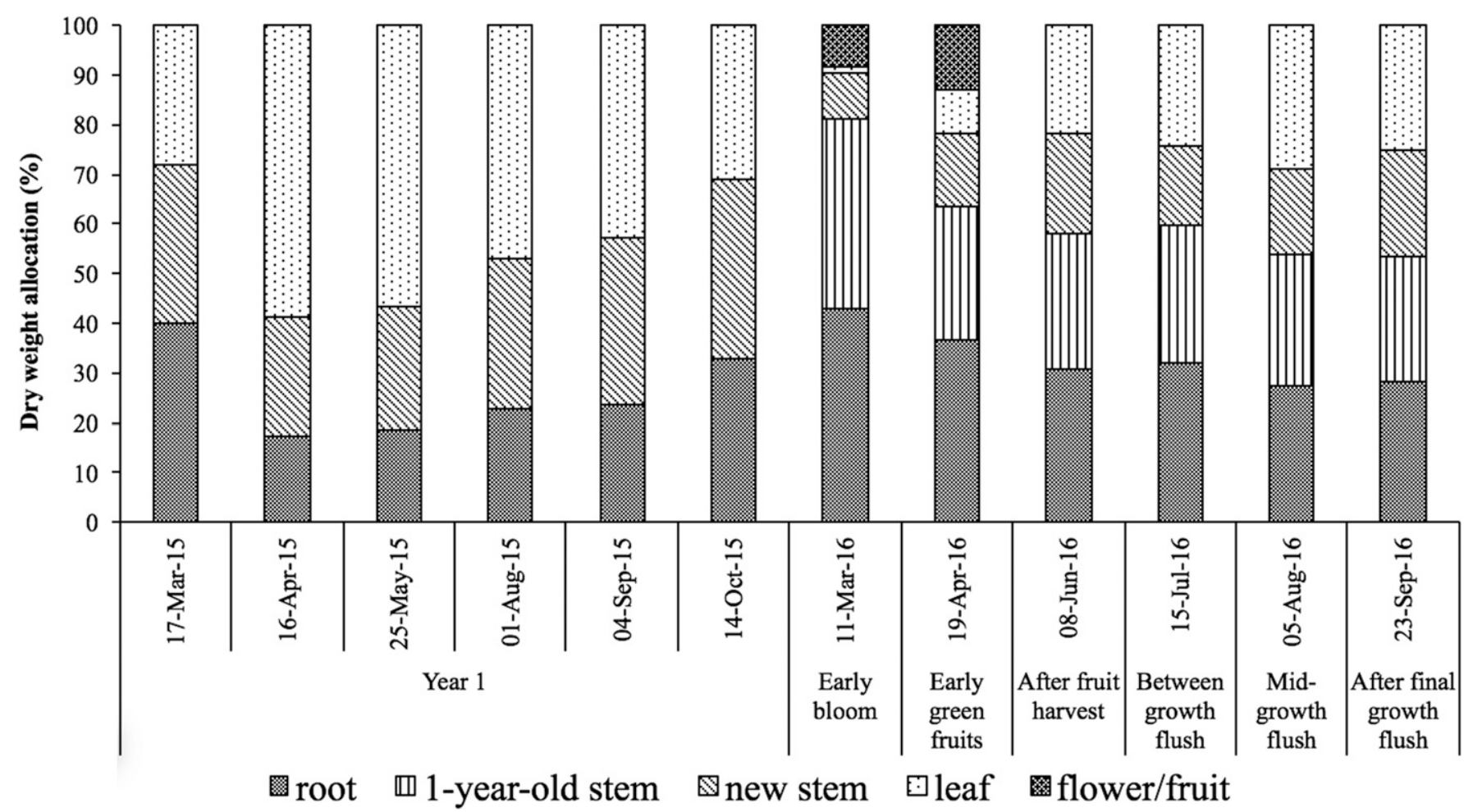

Fig. 2. Dry weight allocation in different tissues of young 'Emerald' blueberry plants grown in 57-L containers throughout two growing seasons in 2015 and 2016. Means of five replicates.

Data analysis. The effects of ${ }^{15} \mathrm{~N}$ application date on each measured variable were analyzed by analysis of variance using the statistical analysis software $\mathrm{R}$ version 3.2.2 ( $\mathrm{R}$ development core team, New Zealand). Comparisons among application dates were performed at the 0.05 level using Tukey's honest significant difference test.

\section{Results and Discussion}

Plant height and area covered by plant canopy. In the first growing season, plant height increased rapidly from mid-April through early August, with the growth rate averaging $0.32 \mathrm{~cm} / \mathrm{d}$ (data not shown). Growth then plateaued from early September through mid-March of the second year. In the second growing season, plant height increased from mid-March through early September, with an average growth rate of 0.26 $\mathrm{cm} / \mathrm{d}$. Plant canopy measurements indicated that plant lateral growth was greater when vertical growth was slower. In the early spring and in fall, lateral growth was greater than the rest of the year, with an average rate of $21 \mathrm{~cm}^{2} / \mathrm{d}$ (data not shown). During fruiting (in April), both vertical and lateral growth slowed, with respective rates of $0.04 \mathrm{~cm} / \mathrm{d}$ and $6.7 \mathrm{~cm}^{2} / \mathrm{d}$.

Total DW and DW allocation. Plant budbreak began in early February, but total DW did not begin to increase until mid-May 2015. Total DW increased continuously from midMay to Oct. 2015, with a 6-fold increase occurring between 25 May and 1 Aug. (Fig. 1). During year 2, total DW increased from mid-April 2016 to the end of the growing season. In winter, a reduction in total DW from $323 \mathrm{~g} /$ plant to $267 \mathrm{~g} /$ plant occurred between Oct. 2015 and Mar. 2016 as a result of leaf abscission. Unlike the results from Banados et al. (2012) in young NHB, total DW continued to increase throughout the harvest stage, which may be attributed to the low fruit yields resulting in a high vegetative growth rate. The greatest rate of total DW increase occurred from early September to mid-Oct. 2015 (averaging $3 \mathrm{~g} / \mathrm{d}$ ) and from mid-July to the end of Sept. 2016 (averaging $4 \mathrm{~g} / \mathrm{d}$ ).

Allocation of total DW to each tissue varied with sampling dates (Fig. 2). In the first growing season, the proportion of total DW allocated to leaves increased rapidly from March to April and then gradually decreased until the end of the season. Conversely, the percentage of total DW allocated to new stems and roots first decreased from March to April and then slowly increased for the remainder of the first growing season from $\approx 24 \%$ to $36 \%$ and from $17 \%$ to $33 \%$, respectively. However, leaves always had a significantly greater proportion of total DW than roots or new stems between April and September in year $1(P<0.01)$. These results are in contrast with the findings of Banados et al. (2012) and White (2006), who found the greatest proportion of DW in blueberry plants was allocated to roots during the first year after planting. In their studies, the plants were NHB grown in the field. Thus, the plants likely had a better developed root system than the container-grown plants used in our study.
In 2016, the greatest proportion of total DW was allocated to stems (the sum of 1 -year-old and new stem), accounting for more than $40 \%$ of total DW. Dry weight allocation to new stems increased from $9 \%$ to $21 \%$ throughout the season, with a brief decline in midsummer. Dry weight allocation to 1 -year-old stems was relatively stable, accounting for $27 \%$ of the total DW from April to the end of September. The proportion of DW allocated to roots decreased significantly from March to June and then remained stable at $\approx 30 \%$. Similar to the first year, root growth mainly occurred from the late summer to the early fall (August and September). Leaves grew rapidly throughout the season, especially after fruit harvest and during midsummer. Generally, from July to September, DW allocation to leaves, roots, and 1-year-old stems did not change significantly and all were significantly greater than DW allocation to new stems. The DW of stems (the sum of 1 -year-old and new stems DW) and roots was positively correlated in both years $(P<0.05$, $R^{2}=0.84$ ) (data not shown), suggesting that shoot and root growth occur concomitantly, which agrees with previous work on blueberry (Abbott and Gough, 1987; Spiers, 1995). Flowers, fruits, or both comprised $8 \%$ to $15 \%$ of the total plant DW when plants were harvested 2 weeks after ${ }^{15} \mathrm{~N}$ application in the early green fruit stage. Banados et al. (2012) reported fruit DW accounted for 4\% to $33 \%$ of total DW on young NHB plants from green fruit to fruit harvest stages. In the present study, fruits were collected during the green fruit stage; thus, DW allocation to fruits would also increase as fruits ripen. 


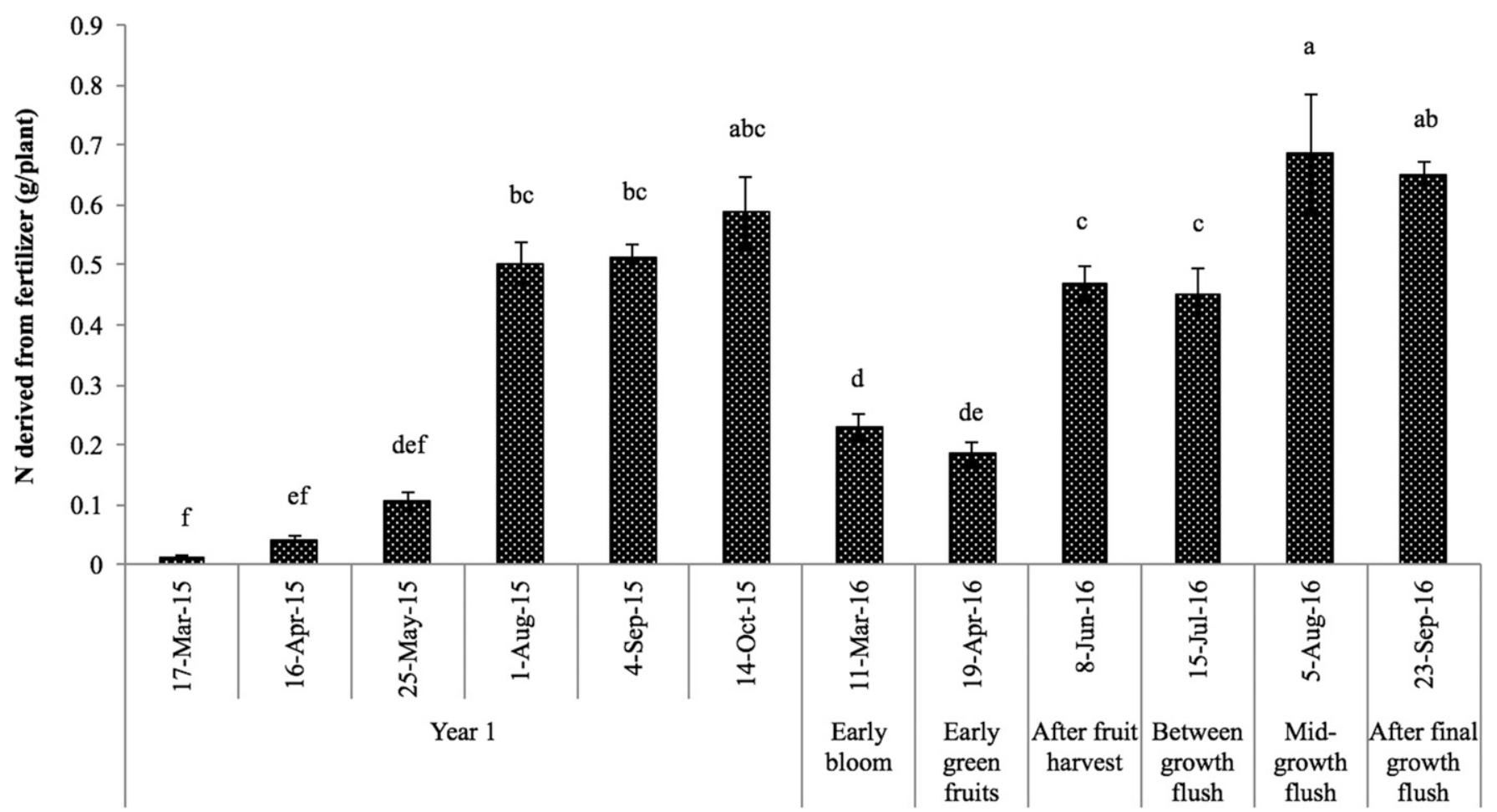

Fig. 3. Nitrogen derived from fertilizer of young 'Emerald' blueberry plants grown in 57-L containers throughout two growing seasons in 2015 and 2016 . Plants were sampled at the indicated dates, which was 2 weeks after ${ }^{15} \mathrm{~N}$ fertilization. Means $\pm \mathrm{SE}(n=5)$. Means with different letters are significantly different at $P \leq 0.05$ according to Tukey's honestly significant difference test.

$N D F F$ and NDFF allocation. The pattern of NDFF change throughout the growing season was similar to the pattern of total DW accumulation (Fig. 3). This finding agrees with the results reported by Banados et al. (2012) on young NHB and Weinbaum et al. (1978) on plum (Prunus domestica L.), indicating that $\mathrm{N}$ is most rapidly taken up when biomass accumulation is greatest. In our study, the greatest biomass increase occurred between September and Oct. 2015 and between mid-July and Sept. 2016. Similarly, the greatest $\mathrm{N}$ uptake occurred in the 2 -week period ending on 14 Oct. 2015 and the 2-week periods ending on 5 Aug. and on

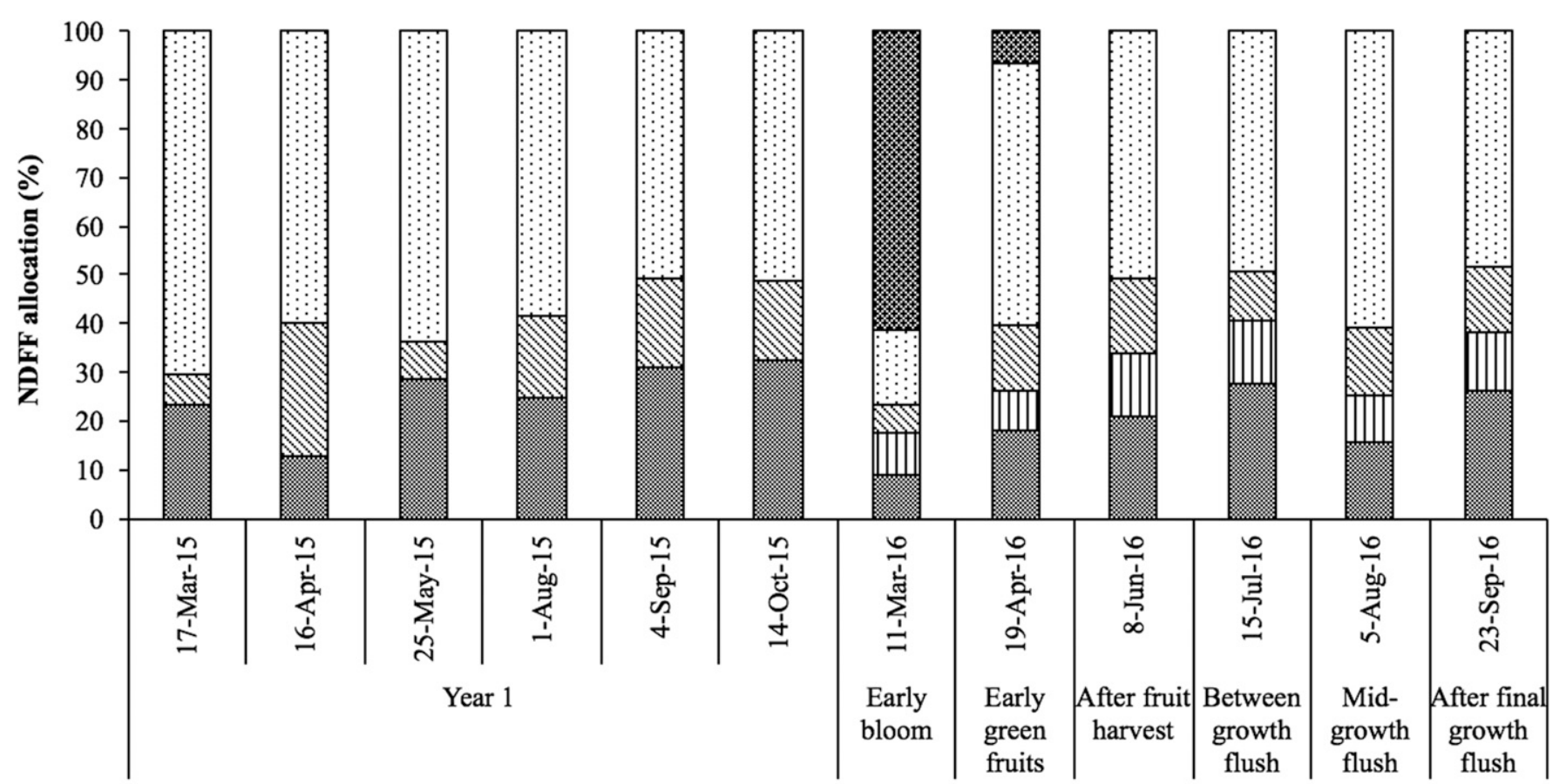

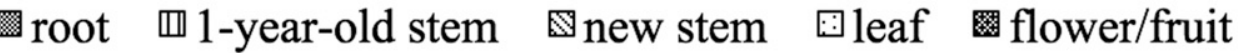

Fig. 4. Allocation of total $\mathrm{N}$ derived from fertilizer to tissues of young 'Emerald' blueberry plants grown in 57-L containers throughout two growing seasons in 2015 and 2016. Plants were sampled at the indicated dates, which was 2 weeks after ${ }^{15} \mathrm{~N}$ fertilization. Means of five replicates. 
23 Sept. 2016. However, biomass accumulation cannot fully explain the differences in NDFF among growth stages. In 2016, plant DW in midgrowth flush was similar to that between growth flushes, but $\mathrm{N}$ uptake in midgrowth flush was $50 \%$ greater than between growth flushes (Fig. 3). In addition, plants accumulated significantly more biomass after the final growth flush than during the midgrowth flush, although $\mathrm{N}$ uptake during these two stages was similar. Thus, although $\mathrm{N}$ absorption by young SHB generally increases as biomass increases, which is similar to results found with 2 -year-old peach (Prunus persica L.) trees (Munoz et al., 1993), factors other than increases in biomass appear to influence $\mathrm{N}$ absorption.

In both years, little $\mathrm{N}$ was taken up (as low as $0.03 \mathrm{~g} /$ plant in 2015 and $\approx 0.21 \mathrm{~g} /$ plant in 2016) from the applied $N$ fertilizer between March and May during the 2-week chase period. This is in agreement with findings on both young and mature NHB, where little $\mathrm{N}$ uptake occurred in the early season (Banados, 2006; Banados et al., 2012). Similar results have also been reported in peach and pear (Pyrus communis L., cv. Williams pear) (Nario et al., 2003; Taylor et al., 1975). The low $\mathrm{N}$ uptake in the first year was likely due, in part, to the small plant size and the lack of well-developed roots. However, the low N uptake in the spring of the second year was likely because early reproductive and vegetative growth used stored $\mathrm{N}$ from roots and stems, as reported by Birkhold and Darnell (1993) in rabbiteye blueberry and Banados et al. (2012) in NHB blueberry. Since N from storage pools was used to support new growth, the demand for external $\mathrm{N}$ was decreased. Although low soil temperatures in spring may also decrease soil $\mathrm{N}$ uptake, the average soil temperature during that time was $19.4{ }^{\circ} \mathrm{C}$, which is within the optimum range for blueberry (Spiers, 1995).

During the two growing seasons, at least, $50 \%$ of NDFF was allocated to leaves at each stage except early bloom in 2016 (Fig. 4), when more than $60 \%$ of absorbed $\mathrm{N}$ was allocated to flowers. Although flowers represented a primary sink for $\mathrm{N}$ during early bloom, NDFF in flowers was $\approx 0.14 \mathrm{~g}$ and only accounted for $22 \%$ of total $\mathrm{N}$ in flowers (averaged $0.65 \mathrm{~g}$ ). Thus, $\approx 78 \%$ of the total $\mathrm{N}$ in flowers was derived from storage $\mathrm{N}$. Similarly, Banados et al. (2012) reported that more than $60 \%$ of total $\mathrm{N}$ in flowers of young NHB was from reserve N. Less than $10 \%$ of the $\mathrm{N}$ from fertilizer applied at the young green fruit stage was allocated to fruits during the 2-week chase period, accounting for only $\approx 1 \%$ of the total $\mathrm{N}$ accumulated in green fruits. This result is supported by previous work on rabbiteye blueberry (Birkhold and Darnell, 1993), suggesting that storage $\mathrm{N}$ is the primary $\mathrm{N}$ source during early fruit development. However, as the $\mathrm{N}$ storage pool decreases, $\mathrm{N}$ remobilization is reduced. Then, current absorbed $\mathrm{N}$ becomes the major supply and thus dilutes the percentage of $\mathrm{N}$ contribution from storage $\mathrm{N}$ (Millard and Grelet, 2010). Banados et al. (2012) reported that up to $75 \%$ of total fruit $\mathrm{N}$ at harvest was from uptake of new $\mathrm{N}$ from fertilizer or the soil. In general, roots accumulated more absorbed N ( $23 \%$ of NDFF) than new stems $(14 \%)$ or 1 -year-old stems $(10 \%)$ in both years.

In conclusion, in the first year after planting, stem, root, and leaf growth occurred mainly in the summer and fall. In the second year, stem DW increased rapidly when vegetative flushes occurred. Root growth was primarily in the early fall. Leaf development began at early bloom and continued throughout the growing season. During spring (March and April), N uptake was low, likely because of small plant size and undeveloped roots (in year 1) or because new growth was supported by remobilization of storage $\mathrm{N}$ from roots and 1-year-old stems (in year 2). The greatest $\mathrm{N}$ uptake generally occurred from late summer to midfall when biomass accumulation was the greatest. During both growing seasons, about half of the total $\mathrm{N}$ derived from applied fertilizer was allocated to leaves, except during early bloom in 2016. Therefore, in our experimental conditions, it appears that spring fertilization requirements of young SHB are minimal and that $\mathrm{N}$ uptake is most efficient when fertilizer is applied from summer through early fall.

\section{Literature Cited}

Abbott, J.E. and R.E. Gough. 1987. Seasonal development of highbush blueberry roots under sawdust mulch. J. Amer. Soc. Hort. Sci. 112:60-62.

Banados, M.P. 2006. Dry weight and 15N-nitrogen and partitioning, growth, and development of young and mature blueberry plants. OR. State Univ., PhD Diss. 10 May 2017. <http://ir.library. oregonstate.edu/xmlui/handle/1957/9649>.

Banados, M.P., B.C. Strik, D.R. Bryla, and T.L. Righetti. 2012. Response of highbush blueberry to nitrogen fertilizer during field establishmentI. Accumulation and allocation of fertilizer nitrogen and biomass. HortScience 47:648-655.

Birkhold, K.T. and R.L. Darnell. 1993. Contribution of storage and currently assimilated nitrogen to vegetative and reproductive growth of rabbiteye blueberry. J. Amer. Soc. Hort. Sci. 118:101-108.

Cheng, L. and L.H. Fuchigami. 2002. Growth of young apple trees in relation to reserve nitrogen and carbohydrates. Tree Physiol. 22:1297-1303.

Danso, S.K., J.B. Bole, and F. Zapata. 1983. A guide to the use of Nitrogen-15 and Radioisotopes in studies of plant nutrition, calculations and interpretation of data. IAEATECDOC-288. IAEA, Vienna. 10 May 2017. <http://www.iaea org/inis/collection/NCLCollectionStore/_Public/ 14/799/14799086.pdf>.

Geßler, A., M. Schultze, S. Schrempp, and H. Rennenberg. 1998. Interaction of phloemtranslocated amino compounds with nitrate net uptake by the roots of beech (Fagus sylvatica) seedlings. J. Expt. Bot. 49:1529-1537.

Gheysari, M., S.M. Mirlatifi, M. Homaee, M.E. Asadi, and G. Hoogenboom. 2009. Nitrate leaching in a silage maize field under different irrigation and nitrogen fertilizer rates. Agr. Water Mgt. 96:946-954.

Hanson, E.J. and J.B. Retamales. 1992. Effect of nitrogen source and timing on highbush blueberry performance. HortScience 27:1265-1267.

Krewer, G.W. and J.M. Ruter. 2009. Fertilizing highbush blueberries in pine bark beds. 10 May
2017. <http://www.smallfruits.org/Blueberries/ production/blueberryfert.pdf $>$.

Mariotti, A. 1983. Atmospheric nitrogen is a reliable standard for natural ${ }^{15} \mathrm{~N}$ abundance measurements. Nature 303:685-687.

Millard, P. 1996. Ecophysiology of the internal cycling of nitrogen for tree growth. Zeitschrift für Pflanzenernährung und Bodenkunde 159:1-10.

Millard, P. and G.A. Grelet. 2010. Nitrogen storage and remobilization by trees: Ecophysiological relevance in a changing world. Tree Physiol. 30:1083-1095.

Munoz, N., J. Guerri, F. Legaz, and E. PrimoMillo. 1993. Seasonal uptake of $15 \mathrm{~N}$-nitrate and distribution of absorbed nitrogen in peach trees. Plant Soil 150:263-269.

Nario, A., I. Pino, F. Zapata, M.P. Albornoz, and P. Baherle. 2003. Nitrogen $(15 \mathrm{~N})$ fertiliser use efficiency in peach (Prunus persica L.) cv. Goldencrest trees in Chile. Sci. Hort. 97:279-287.

Percival, D.C., D.E. Janes, D.E. Stevens, and K. Sanderson. 2002. Impact of multiple fertilizer applications on plant growth, development, and yield of wild lowbush blueberry (Vaccinium angustifolium Aiton). Acta Hort. 626:415-421.

Rempel, H.G., B.C. Strik, and T.L. Righetti. 2004. Uptake, partitioning, and storage of fertilizer nitrogen in red raspberry as affected by rate and timing of application. J. Amer. Soc. Hort. Sci. 129:439-448.

Spiers, J.M. 1995. Substrate temperatures influence root and shoot growth of southern highbush and rabbiteye blueberries. HortScience 30:1029-1030.

Taylor, B.K., B. Van Den Ende, and R.L. Canterford. 1975. Effects of rate and timing of nitrogen applications on the performance and chemical composition of young pear trees, cv Williams'. Bon Chretien. J. Hort. Sci. 50:29-40.

Thomas, B.P., L. Law, Jr., and D.L. Stankey. 1979. Soil survey of Marion County area, Florida. US Department of Agriculture Soil Conservation Service, Washington, DC. 10 May 2017. $<$ https://www.nrcs.usda.gov/Internet/FSE_ MANUSCRIPTS/florida/FL608/0/Marion.pdfs.

Throop, P.A. and E.J. Hanson. 1997. Effect of application date on absorption of 15 nitrogen by highbush blueberry. J. Amer. Soc. Hort. Sci. 122:422-426.

Vitosh, M.L., J.W. Johnson, and D.B. Mengel. 1995. Nitrogen losses from soil. 10 May 2017. <http:// fieldcrop.msu.edu/uploads/documents/Nitrogen $\%$ 20losses\%20from\%20soil.pdf>.

Weinbaum, S.A., M.L. Merwin, and T.T. Muraoka. 1978. Seasonal variation in nitrate uptake efficiency and distribution of absorbed nitrogen in non-bearing prune trees. J. Amer. Soc. Hort. Sci. 103:516-519.

White, L.D. 2006. The effect of pre-plant incorporation with sawdust, sawdust mulch, and nitrogen fertilizer rate on soil properties and nitrogen uptake and growth of 'Elliott' highbush blueberry. OR. State Univ., MS Diss. 10 May 2017. <http://ir.library. oregonstate.edu/xmlui/handle/1957/1363>.

Whitehead, D.C. and N. Raistrick. 1993. The volatilization of ammonia from cattle urine applied to soils as influenced by soil properties. Plant Soil 148:43-51.

Wild, A. and K.C. Cameron. 1980. Soil nitrogen and nitrate leaching, vol. 2, p. 35-70. In: P.B Tinker (ed.). Soils and agriculture. Critical Reports on Applied Chemistry. Blackwell Scientific Publications, Oxford.

Williamson, J.G. and E.P. Miller. 2009. Effects of fertilizer rate and form on vegetative growth and yield of southern highbush blueberry in pine bark culture. HortTechnology 19:152-157. 